\title{
Voluntarism and realism in medieval ethics
}

\author{
John Haldane University of St Andrews, Scotland
}

\section{Author's abstract}

In contrast to other articles in this series on the history of moral philosophy the present essay is not devoted to expounding the views of a single author, or to examining a particular moral theory. Instead it discusses an important dispute between two medieval accounts of the relation between theological and moral propositions.

In addition to its historical interest this debate is important both because it connects earlier and later ethical thought - being influenced by Greek moral theories and influencing subsequent European philosophy - and because it concerns issues that remain important to philosophers and to those who claim that their ethical beliefs are dictated by religious convictions.

'The point which I should first wish to understand is whether the pious or holy is beloved by the gods because it is holy, or holy because it is beloved of the gods.'

Plato. Euthyphro 10a

\section{I}

Moral philosophy is not much older than Plato and certainly the Dialogues present the first systematic attempt to grasp the nature of moral truth. This gives them one kind of priority among ethical writings but they also enjoy primacy on two other counts. They are philosophically great works which raise and discuss most of the fundamental problems that have concerned subsequent thinkers, and relatedly, they have been more influential than other philosophical writings. Accordingly, when trying to make sense of unfamiliar ideas in the history of the subject it is always worth asking: How do these thoughts relate to Plato's concerns? Since often what is at issue is a problem introduced with great clarity in one of the Dialogues.

This is certainly the case with the topic to be discussed here. Unlike other essays in this series this article is not concerned with the ideas of a single thinker, nor even with those of a single philosophical

\section{Key words}

Voluntarism; ethical realism; medieval moral philosophy; religious ethics; naturalism. tradition. The reference to medieval ethics in the title therefore, is not to a movement whose members were united by their common view of the nature of morality $\vec{\omega}$ Rather it indicates a period in the history of philosophy roughly bounded by the birth of Scotus Erigena 'John the Scot' (c 800-870) and the death of Nicholas of Cus $\vec{a}$ (1401-1464) during which a wide range of morat theories was developed.

Of course, there is one crucially important common thread running through Western medieval philosophy $\odot^{\circ}$ the assumption of the truth of the central doctrines of Judaeo-Christianity. The religious dimension is of general relevance when trying to understand the concerns of writers in this era and has particula significance for the present attempt to explain the fundamental division among moral theories of th\& period. The latter task is also helped by looking to Plato. The main point at issue among the medievals was the relation between morality and religion between the moral character of a person, action or state़e of affairs and God's attitude to these things. And the philosophical problem this raises is easily and acutely stated in a form derived from Socrates's question to Euthyphro quoted above: Does God love and. command what is good because it is good, or is it goo@ because God loves and commands it?

Those who asserted the latter are thereby known as Voluntarists from the Latin voluntas, (inclination ots will): they claim that God's inclination and will give. things their moral status. Those who argue for the former contrary thesis are best described as Realists since they hold that ethical propositions are true or false in virtue of how things are in reality independently of what attitudes anyone has towards them - including those of God Himself.

The interest of this dispute in the present context isD threefold. Firstly, it was important in shaping moraf philosophy in the intervening period between Classica antiquity and the Modern age and has had considerable influence on subsequent ethical, political, legal and? theological thought. Secondly, while in general religious belief has declined dramatically since the middle ages it is apparent that Christians are among the most active and committed participants ino contemporary discussion of matters of social and moraE. concern, for example defence policy, foreign aid an 
sexual and medical ethics and it is usual for them to relate their views on these issues (and their practice) to what they believe to be the will of God. Thirdly, consideration of the Euthyphro dilemma and of medieval responses to it quickly leads one beyond its theological dimension to a position from which one can see that what underly this issue are a set of problems not only for religious ethics but for moral philosophy generally, chief among which is that of giving account of the relationship between ethical judgements and the various non-moral claims which are taken to support them.

\section{II}

In regard to the first point of interest the three main contributors to the voluntarism/realism dispute belong to the classical period of medieval philosophy. They are: St Thomas Aquinas (1224-1274); Duns Scotus (1266-1308); and William of Ockham (1290-1350). Each was a major figure who made important contributions to various branches of the subject and who viewed philosophy as essentially systematic, with the corollaries that their views on ethics are best understood in the context of a study of their overall philosophies and that the differences between them with regard to the character of morality are paralleled elsewhere, for example in their theories of knowledge and of the nature of reality in general. In the present circumstance, however, it is possible to illuminate the central elements of their moral philosophies by following the order of their lives and taking the position advanced by Aquinas as providing a starting point and background for the voluntarist/realist.

\section{III}

Since Aquinas' moral theory is itself the subject of another essay in this series (1) I shall simply indicate something of its general character as this bears upon the issue of Divine Commands. Firstly, then, his view is naturalist, teleological and eudaimonistic. That is to say he argues for an account of moral value as consisting in the obtaining of a state of affairs in which one's activity is in accord with the perfection of one's nature qua human being. The natural end of human life is participation in the life of God through a beatific vision of Him but this involves the perfection of every aspect of human nature: intellectual, emotional, social and organic. Thus questions about the conduct of life are to be answered by reference to the character of human flourishing. Those things are good which promote our natural well-being and thereby lead to perfect happiness. Correspondingly, evil consists in the impediment of life's progress - and at worst its destruction.

In the terms of the dispute Aquinas is clearly a realist since he takes the truth of moral propositions to be wholly determined by the natural facts which obtain independently of anyone's conception of them. Given the existence of any being with a natural constitution, it is a determinate and wholly objective fact whether or not it is good for it to be in a certain state or to behave in a certain manner. Inhaling solvents causes damage to cells thereby impairing the proper functioning of the human body with the result that the addict is unable to realise his or her natural potential. These empirical facts explain why glue-sniffing is a bad practice, a vicious habit, and are evidence for the normative judgement that it ought not to be engaged in.

For Aquinas, therefore, the moral vocabulary and the propositions into which it enters have their proper foundation in non-moral descriptions of the created order. Of course without God there would be no creation and ipso facto no moral truths concerning the behaviour of parts of it. In the sense in which $\mathrm{He}$ is the author of all things, therefore, God is the author of morality. For He ordains the ends of His creatures.

'Since all natural things have been directed by a certain natural inclination toward their ends by the first mover, God, whatever is willed or intended by God is that to which everything is naturally inclined. But inasmuch as God's will can have no other end than Himself, and he is essentially goodness, everything must be naturally inclined to good' (2).

Nonetheless, God does not ordain moral facts independently of this general creative activity. The teleology or proper pattern of development of an organism is both necessary and sufficient to establish the set of values appropriate to it independently of whatever attitude God might subsequently adopt. As the quoted passage indicates, Aquinas maintains that God is Himself essentially good and that $\mathrm{He}$ makes creatures such that in their perfected state they participate in His glory. From this St Thomas concludes that it would be contrary to the nature of God to command creatures to behave in ways harmful to them (3) and thus he is able to claim that the two expressions:
a) 'That which is good', and
b) 'That which God commands',

are necessarily co-extensive, ie apply to all and only the same things. Where he differs from the voluntarist is in denying that $\mathrm{a}$ ) and $\mathrm{b}$ ) are co-intensive ie have the same meaning. God commands benevolence but its goodness is logically independent of this fact. Were $\mathrm{He}$, contrary to His own benevolent nature, to will that murder be done this would be wrong and His belief that murder is good would be false. Thus Divine Commands do not serve to create moral features but to disclose them to creatures whose ignorance of their own nature and of what best befits it would otherwise lead them to harm themselves (4).

Aquinas's moral philosophy has much to commend it and his response to the Euthyphro dilemma is subtle. Indeed this version of realism came to be widely adopted in the following centuries in conscious opposition to voluntarism. There are, however, problems facing both the general position of ethical 
naturalism and its theological implications. These difficulties are best approached by turning to the work of Scotus who knew and was partly critical of St Thomas's moral theory.

\section{IV}

Like Aquinas, Scotus argues that the natural constitution of things establishes a range of values for them and that while God could act to eliminate the goodness of intellectual endeavour or friendship, say for he has absolute power (potentia absoluta), this could onty be done by destroying the actual natural order in virtue of which these features are good. This suggestion goes some way to meeting the theological claim, which is the principle support of voluntarism, that by His will God can achieve all things. However, it is neither adequate nor appropriate as an explanation of those episodes related in Judaeo-Christian Scripture in which God is presented as dispensing with the natural moral law (lex naturalis) and commanding actions apparently at odds with it. The two cases most frequently discussed by medieval authors are God's command to Abraham to sacrifice his son Isaac (5) and His order to the Israelites to despoil the Egyptians (6), in which it seems He prescribes murder and theft.

In discussion of the second example Aquinas appeals to the notion of mutatio materiae (7). Ethical naturalism proposes that values are properties of properties, that is: they are features which supervene, or are consequent upon natural characteristics of things. This supervenience thesis implies that if two things are alike in all their natural properties they are alike also in their moral qualities, and that if something ceases to exhibit a moral feature it also has changed with regard to its natural characteristics. The possibility mentioned above of God's making false some particular claim, for example about the value of friendship, by destroying the world is a dramatic and limiting case of the latter implication of the supervenience thesis. Clearly, though it is not appropriate to invoke this possibility in explanation of how God was able, in the cases quoted, to dispose with the natural law precepts against murder and theft. However, a logically similar move can be made by means of mutatio materiae; the proposal being that while the prohibition against stealing another's property still obtains, God has the power to change the circumstances of an action so that what would otherwise have been theft is rendered permissible - though it retains the appearance of robbery. In the particular case of the Israelites despoiling the Egyptians the usual suggestion is that the mutatio involved the transfer by God of property which is truly His from one group to the other (8).

Ingenious as this response may be, Scotus perceives its implausibility as an explanation of all the problem cases presented by Scripture (9) where the material character of what God wills is no different from actions which reason judges are naturally bad. Accordingly he tries to show how God has the power to dispense with certain moral requirements while retaining the basic assumption of ethical realism, viz, that values are objectively fixed by nature $(10)$. This attempt to trace a via media is perhaps ultimately incoherent and collapses into one or other of the opposing positions but it introduces some interesting and important ideas.

Firstly, Scotus points out that ethical naturalism may explain why actions, character traits, etc, are good or bad, virtuous or vicious but it seems unable to account for such features of morality as requirements, prohibitions and duties. By studying human teleology one may derive reasons in favour or against a particular action but this kind of thinking seems to belong to the province of prudence and to concern what is naturally good (naturaliter bonus) rather than to be strictly moral deliberation, the proper object of which is obligation. The gap between natural value and duty is bridged in Scotus's theory by the Divine Will: if and only if God commands it does an action which it would in any case be good to perform become obligatory (likewise God's command is necessary and sufficient to render a bad action prohibited).

This thought is both clever and philosophically fruitful. It makes good a deficiency in Aquinas's ethical naturalism by providing an explanation of duty. It remains fundamentally realist in claiming that while the deontological form and binding force of moral requirements derive from God's will yet their content is provided by the objective good for man. It shows the necessity of revelation, as reason alone can only determine the value of actions and not whether they are commanded. And finally, it allows the possibility of Divine dispensations, since God can choose on some occasions not to command a good action or prohibit a bad one and thereby deprive them of their customary obligatory status.

Notwithstanding its merits, however, this qualified naturalism is no better placed than Aquinas's appeal to mutatio materiae to explain cases in which God is presented as entirely transforming the moral character of an action; not merely ceasing to command the good but apparently commanding the bad. It is in order to account for these episodes that Scotus introduces a second important (though less plausible) idea which involves a further move in the direction of voluntarism. Scotus assumes that the basic principles of the natural law which are ascertainable by reason and are also 0 given (with added deontological force) through $N$ revelation are necessary truths. Thus he concludes that $\underset{\mathrm{C}}{\mathrm{N}}$ in all possible worlds it is wrong to commit murder and not even God can dispense with this fact.

'[The primary precepts of the law of nature] are either $\stackrel{\mathbb{P}^{+}}{+}$ necessary principles [ethical axioms] known through $\frac{T}{0}$ understanding their terms, or conclusions following $\frac{\vec{D}}{\mathbb{D}}$ from them by [logical] necessity. But in one way or $\stackrel{?}{\mathcal{P}}$ another they possess necessary truth. Therefore, God $\stackrel{\mathbb{Q}}{\mathscr{Q}}$ cannot make them to be false. Therefore, $\mathrm{He}$ cannot make what they command to be done to be good, and $\varnothing$ what they prohibit, not to be evil; and consequently, He cannot make such forbidden cases to be permitted' (11). 
The argument can be presented simply as follows:

1) God cannot perform a logically impossible feat.

2) It is logically impossible to make a contradiction true.

3) The negation of an ethical axiom, for example murder is wrong (thus: it is not the case that murder is wrong), is a contradiction.

4) Therefore, God cannot dispense with, ie negate, ethical axioms.

Ockham solves the problem presented by the Biblical cases by denying this conclusion but as we shall see this involves an unacceptable cost. Scotus meanwhile accepts premises 1) -3) and the conclusion they entail, but suggests that there is a broader conception of the natural law in which it includes, as well as axioms and their logical consequences, a number of secondary precepts which while being 'consonant' (sic) with the former are logically distinct from them and are not themselves necessary truths (11).

Consequently no contradiction is involved in negating one of these and ipso facto it is within God's power to do so if $\mathrm{He}$ chooses. Scotus discusses the example of private ownership and suggests that while this may be good in some circumstances it is not absolutely so and hence God may require that someone be deprived of their property. Thereby an action which would otherwise have been bad is made good.

It is important to recognise that the distinction Scotus appeals to is unconnected with the Thomist mutatio materia solution. Scotus is not claiming that a precept remains true but that God changes the circumstances so that it no longer applies in the particular case. Rather his proposal is that any member of the class of secondary moral precepts can be dispensed with by God in a circumstance which is in all other respects identical to situations in which the same precept applies. Put in this way it is clear that Scotus has departed from the position of ethical naturalism. For, what he proposes directly conflicts with the supervenience thesis stated above to which realism is committed. More precisely his moral theory straddles two positions and seeks to retain the strengths of each while avoiding their weaknesses. For all that his thought is philosophically creative, however, the final product is irrevocably flawed. It attempts to bind together opposing elements and only failure can result. One must choose between realism and voluntarism and cannot have them both.

\section{V}

The most forthright statement of the latter position is that provided by Ockham according to whom 'Evil [in respect of action] is nothing other than doing something when one is under an obligation to do the opposite' (12). That is to say, the moral is simply constituted by God's will. Some later writers, particularly in the tradition of Protestant Christianity, have been drawn towards the voluntarist position. John Calvin, for example, claims that 'God's will is so much the highest rule of righteousness that whatever $\mathrm{He}$ wills by the very fact that $\mathrm{He}$ wills it, must be considered righteous' (13). No writer other than Ockham, however, has produced such powerful theological and philosophical arguments for voluntarism and anyone disposed to reject it must take account of these.

The central assumption of Ockham's case against ethical realism is that God is omnipotent and free to will (and thereby bring about) whatever $\mathrm{He}$ chooses. Certainly God cannot do what is logically contradictory but this is not a limitation on His part. Any statement purporting to be a description of God's performing a logically impossible feat is itself a contradiction and, therefore, not possibly true. For example, to say that it is logically impossible that $2+2=5$ is to say that there is no possible world in which $2+2=5$. If God could do the logically impossible then the following statement could be true: God made a world in which $2+$ $2=5$ and there is no possible world in which $2+2=5$. However, this statement is contradictory and hence could never be true; consequently it is simply incoherent to suppose that anyone, even God, could achieve the logically impossible.

For Ockham, then, God can do anything that is not contradictory. Moral propositions he contends are not necessary, ie unlike Aquinas and Scotus he argues that there is no incoherence in supposing that murder should be done - the concepts involved in this thought are not contradictory. One may be mistaken in believing it but not in the way one would be wrong in believing that a bachelor is married. Accordingly, it is within God's power to will that murder be done or that it not be done. To propose that His choice must be constrained by the moral facts and, therefore, that $\mathrm{He}$ could not bring it about that murder is obligatory is in Ockham's view to impose a non-logical limit on God's power. In short, it is to suggest that $\mathrm{He}$ is not omnipotent, which in turn is to imply that the being in question is not God.

Starting from the assumption of Divine omnipotence the conclusion is reached that it cannot be the case that God commands something because it is (independently) good but that something is good because and only because God commands it (14). In the terminology employed earlier, Ockham's view is that the expressions 'is good' and 'is commanded by God' are co-extensive - true of all and only the same things, because they are co-intensive - have the same meaning, ie are synonymous.

The strength of this position is further revealed by considering a familiar argument against it. If voluntarism were true then if God commanded murder and theft, etc, these would be good; but this is absurd for they are clearly evil and could never be otherwise; consequently either God can do evil or voluntarism must be false. Ockham's reply is that this argument is simply question-begging. He allows that we believe such actions to be wrong and contrary to the law of God and explains these facts by pointing to Scripture and indicating where God forbids them. The latter event is 
the complete explanation of their evil since Divine prohibition constitutes moral badness. It also shows why if God were by His absolute power and freedom to command them, murder, theft and even misotheism (hatred of God) would be virtuous.

'For as was said, deformity in an act of commission is only the very act itself elicited against the divine command and expresses nothing else at all. And if you say that God would then sin in causing such a deformed act, just as the created will sins when it causes such an act, I reply that God is under obligation to no one; and hence $\mathrm{He}$ is neither bound to cause that act, nor the opposite act, nor not to cause it' (15).

This reply also provides a solution to the Problem of Evil, ie the argument that the occurrence of natural and moral evil is incompatible with the existence of an omnipotent, omniscient, omnibenevolent Creator. If God's will is necessary and sufficient for the goodness of whatever it brings about then whatever God has made is good. Thus God cannot be charged with causing or permitting the occurrence of evil.

It should be clear that Ockham's espousal of strict voluntarism is not unsupported piety. He takes it to be logically implied by Christian theology - to be derivable from the Divine attributes - and to show the necessity of Revelation as the only means by which we could be apprised of God's Will.

\section{VI}

During and after the Reformation the dispute between realism and voluntarism came to be aligned with more general theological and philosophical disagreements between Catholic and Protestant Christianity. The reasons for this are complex but relate to their different conceptions of reason, will, human nature and the relationship between God and man. Outside of the Christian religion the problem of the logical relationship between the Law of God and moral goodness is a main theme of Jewish and Muslim philosophy from the middle ages onwards (16).

The decline of religious belief may have removed the issue from the centre of current moral philosophy but it has not yet been resolved and remains an important topic for enquiry. The foregoing sections show something of the philosophical wealth of medieval discussions and of why current neglect of them is unfortunate. As well as their general interest they are valuable for the way in which they articulate a clear conceptual structure within which thought about religious ethics may proceed. This said it is appropriate to conclude with some brief remarks about the relative merits of realism and voluntarism.

Ockham derives from Scotus the insight that morality is not simply concerned with value, or the good, but also with obligation, or the right, and in addition takes from him the idea that duty is only explicable by reference to a person. These thoughts together with his concern for the omnipotence and freedom of God yield the view that 'is good' and 'is commanded by God' have one and the same meaning so that whatsoever God might command would be good. However, this thesis faces two problems.

Firstly, even if voluntarism is true it remains the case that we make moral judgements independently of knowing (or even considering) whether they correspond to God's will. The moral values and principles appealed to in such judgements constitute our ethical world view and it is in large part by comparison with it that we assess the claim of someone or something to be a source of moral insight. The criterial status of this world view has the consequence that were it claimed by $\mathrm{X}$ that God now commands murder, torture and rape we should rightly discount X's testimony. Thus, even if God's commands constitute the moral facts our naturally formed beliefs are our only guide to them.

Secondly, it is not at all clear what it means to claim that God's approval creates the moral order in the manner required by voluntarism. Earlier it was seen that Aquinas regards moral features as characteristics of natural properties of things. This accords with our practice of giving reasons for our moral judgements by appealing to other features of the items in question. Voluntarism by contrast supposes that everything can remain exactly the same yet the moral facts alter through a change in God's attitude to the world. This implies that God's view of how things should be is unconstrained by how they actually are and in turn suggests an account of $\mathrm{Him}$ as irrational and capricious - taking attitudes to the world regardless of its character.

Ockham was drawn to voluntarism out of respect for the Divine attributes but the price of unrestricted moral omnipotence is the ascription to God of irrational, ethical subjectivism. If this is to be avoided God must be viewed as issuing commands related to the actual character of the world $\mathrm{He}$ has created: commanding the good because it is good. Whatever may be the correct version of it, ethical realism presents itself as the only credible option. This conclusion should be welcome for it implies that religious believers and others can engage in rational discussion in agreement that, so far as concerns the good at least, (17) the final authority is simply that of the facts.

Fohn Haldane BA BA PhD, is Lecturer in the Department of Moral Philosophy and Director of the Centre for Philosophy and Public Affairs, University of St Andrews, Fife, Scotland, KY16 9AL.

\section{References}

(1) McInerney R. Aquinas' moral theory. Fournal of medical ethics 1987; 13:31-33.

(2) Aquinas, De veritate, Q 22, al.

(3) Aquinas, Summa contra gentiles, I, c 95.

(4) Aquinas, Summa theologiae, Ia, q l, a 1.

(5) Genesis 22. 
(6) Exodus 11 v 12.

(7) Aquinas, Summa theologiae, Ia, Ilae, q 100.

(8) See reference (7): q 100, a 8.

(9) There are several episodes, especially in the Old Testament, in which God is apparently portrayed as either enjoining, or Himself performing actions contrary to precepts of the Law. In addition to the Genesis and Exodus examples see: Foshua 6:21 and Ezekiel 16 (for cases of mass murder) $\mathcal{F} o b 1$ (for the seemingly gratuitous infliction of suffering) and Hosea 1 (for prostitution and adultery).

(10) Scotus, Opus oxoniense, III, and Questiones quodlibetales q 18, a 1: 'The source of moral goodness and badness'.

(11) Scotus, Opus oxoniense, III, d 37.

(12) Ockham, Reportatio, II, q 5.

(13) Calvin, Institutes of the Christian Religion, 3, 23, 2.

(14) Ockham, Reportatio, IV, q 9.

(15) Ockham, Reportatio, III, q 12.

(16) Leaman O. An introduction to medieval Islamic philosophy Cambridge: University Press, 1985: Ch 4.

(17) As regards moral obligation the view developed by Scotus discussed in Section IV has much to commend it though I cannot explore it further here.

\section{Select bibliography}

Unfortunately there are few good introductions to medieval philosophy. Among the best is F C Copleston, A History of Medieval Philosophy (London: Methuen, 1972) and for more detailed accounts of the work of the authors discussed above see the relevant chapters of his History of Philosophy, Vols II and III (London: Burns Oates \& Washbourne, 1950 and 52). A further useful source of material is The Cambridge History of
Later Medieval Philosophy (eds) Kretzman, Kenny and Pinborg (Cambridge: University Press 1982), though its contents reflect the fact that most of the contemporary interest in the middle ages is concerned with its logic and metaphysics.

Fashion also explains the dearth of studies of medieval moral philosophy. Of those available three deserve mention: D J O'Connor, Aquinas and Natural Law (London: Macmillan, 1967), R McInerney, Ethica Thomistica (Washington DC: the Catholic University of America Press, 1982), and A S McGrade, The Political Thought of William of Ockham (Cambridge: University Press, 1969). Readers wanting a further brief introduction to moral philosophy during this period might consult Haldane J. Medieval and Renaissance Ethics, in P. Singer (ed) A Companion to Ethics (Oxford: Blackwell, forthcoming).

As regards primary sources apart from writings of Aquinas translations of medieval texts are rare and not easily available. The Summa Theologiae of St Thomas has been published in 60 volumes (London: Blackfriars and Eyre \& Spottiswoode, 1963-75) and his Summa Contra Gentiles in 4 volumes (ed) A G Pegis et al (Notre Dame University Press, 1975). The Quodlibetal Questions of Scotus are translated by Alluntis \& Wolter as God and Creatures (Princeton: University Press, 1975). Relevant material is contained in Ockham: Philosophical Writings (ed) Boehner (Indianapolis: Bobbs Merrill, 1964). Finally, short extracts from the work of Scotus and Ockham are included in Hyman \& Walsh (eds) Philosophy in the Middle Ages (Indianapolis, Hackett, 1973).

On the general issue of religious ethics and the Euthyphro problem see the collection of essays Divine Commands and Morality (ed) Helm, (Oxford: University Press, 1981) and for additional relevant literature consult the bibliography contained in this volume. 